\title{
"A Press with Such Traditions": Oxford University Press of Canada
}

\section{Ruth Panofsky}

On Tuesday, Io August 1904, when Oxford University Press established a branch in Canada, ${ }^{2}$ it joined a small but significant group of publishing houses already operating in Toronto. By the turn of the century, Toronto had become a centre for Canada's burgeoning publishing industry, home to the Copp Clark Company, W.J. Gage and Company, and the Methodist Book and Publishing House (later Ryerson Press), for example. When Oxford University Press set up shop on "Booksellers' Row"3 at 25 Richmond Street West, the company sought to consolidate its presence in the small Canadian market with a view to establishing itself as an important branch. Eight years earlier, in September 1896, Oxford had opened its first branch operation in New York. The founding of a second branch in Toronto served, in fact, to widen Oxford's presence in North America. By 1929, the Toronto branch could announce with "great pride" that it represented "a Press with such traditions, and such a record of useful and important work, not only in the development of printing but in the History of England." 4 After twenty-five years in Canada, Oxford University Press had begun to realize its hopes for expansion.

I Ruth Panofsky is Associate Director of the Joint Graduate Programme in Communication and Culture at Ryerson University. Her most recent publications include Adele Wiseman: Essays on Her Works and Lifeline, a volume of poetry. She thanks Joanna Gertler, Laura Macleod, Martin Maw, and Phyllis Wilson of Oxford University Press; Jan Walter of Macfarlane Walter \& Ross; Jim Armour, Vivian Luong, Roy MacSkimming, and Bill Toye for their assistance.

2 Journal entry, Frederick Hall, Oxford University Press archive, Oxford.

3 Wilfrid Ford, "Early Days with Oxford in Canada: Some Reminiscences," Oxford University Press Canadian Branch 1904-1954 [Toronto: Oxford UP, 1954] 16.

4 From Little York to Oxford: The Oxford University Press Canadian Branch, Its Affiliations and Historic Environment 1904-1929 [Toronto: Oxford UP, 1929] I2. 
Oxford's British roots, always emphasized as a source of pride by the Canadian branch, still are celebrated today. Over the past one hundred years, and especially in the period following the Second World War when it was instrumental in developing Canadian letters and in shaping the culture of Canada, Oxford University Press Canada has retained the British tradition of publishing useful, important, and attractive books. As this essay will show, Oxford Canada developed as a largely autonomous branch of its parent company in England. Moreover, having weathered the vagaries of economic uncertainty that always have characterized the publishing industry in this country, Oxford remains committed to the production of Canadian books that reflect the "dignity of the business."

Prior to the establishment of the Toronto branch, S.G. Wilkinson, representative of Oxford University Press in London, travelled across Canada as far west as Winnipeg to promote and sell Oxford books. In his capacity as Wholesale and Trade Manager of the Methodist Book and Publishing House, S.B. (Samuel Bradley) Gundy frequently purchased Oxford titles from Wilkinson. A veteran of Canadian publishing, Gundy had worked for W.J. Gage and Company before joining the Methodist Book and Publishing House. Impressed by Gundy, who was familiar with Oxford's list, Wilkinson appointed him Manager of the Toronto branch with the promise of a "free hand to develop the business" (S.B. Gundy to William Briggs, 8 January 1904), ${ }^{6}$ a large salary, and a share of profits. From 1904 until his death in 1936, Gundy devoted himself to consolidating Oxford's place among Canadian publishing houses.

The son of a Methodist minister, S.B. Gundy was born in Aurora, Ontario, raised in Toronto, and educated at Ryerson School. A cantankerous man of legendary "wrath," that were poorly suited to the business of publishing. Prior to the Second World War, most titles available in Canada were produced either in Britain or the United States and were shipped as plates, sheets, or books to local agency or branch offices. Throughout Oxford's early years in Canada, Gundy oversaw the regular delivery from overseas of crates of books to 25 Richmond Street West, a building without an elevator. Oxford occupied the basement, the

5 From Little York to Oxfords.

6 Archives of the United Church of Canada, Victoria University Archives in the University of Toronto, file 24, box 10 .

7 Ford 16. 
ground floor, and part of the second floor of the building. Wilfrid Ford, who worked at Oxford during Gundy's tenure as Manager, recalled that "[d]elivery of crates to the basement was taken down a slide of planks but, though we were powerless to control their rate of descent, too many books did not seem to get damaged" (I6). In spite of its inadequacies - fortunately, an elevator and electric lighting soon were installed - Oxford University Press purchased 25 Richmond Street West in 1905. No doubt, Gundy's ire was provoked when several months later, on 25 December 1905, a fire broke out causing $\$ 40,000$ in damage to the building's contents. Ford remembers that Oxford "Bibles were so severely scorched within their boxes that the ... edges were quite brittle and broke at a touch"(I8). In 1928, after a second fire ravaged "most of the premises at Richmond Street," Oxford temporarily relocated to Victoria Street.

The following year, Gundy oversaw the company's move to Amen House at 480 University Avenue, a Tudor-style building designed specifically for Oxford University Press by Toronto architects Henry Sproatt and Ernest Rolph. After twenty-five years of operating a publishing house in inferior premises, Gundy appreciated the grandeur of Oxford's new, elegantly appointed offices.

From 1904 onward, Oxford Bibles, and later the Canadian Prayer and Hymn Book, sold exceedingly well for the company. In 1913, Gundy issued the first title to carry the Oxford Canada imprint, The Oxford Book of Canadian Verse, an anthology prepared by poet William Wilfred Campbell, with scholarly assistance from John D. Logan. In publishing The Oxford Book of Canadian Verse, Gundy sought to produce a "comprehensive" anthology that would "document both the origins and directions of the Canadian literary tradition." Campbell's edition, which "provided access to the emerging literature of the young dominion," desire on Oxford's part to foster Canadian literature through the publication of groundbreaking anthologies. It would be decades, however - not until the 1940s - before Oxford's list would include a number of Canadian titles, and not until the 1960s, as this paper

8 "Our World-wide Organization," Clarendonian [Oxford UP] ns 2I.2 (Mar. 1967): 54 .

9 David Latham, "Anthologies in English: Poetry," The Oxford Companion to Canadian Literature, ed. Eugene Benson and William Toye, $2^{\text {nd }} \mathrm{ed}$. (Don Mills, Ont.: Oxford UP, 1997) 38.

Io Ann Cowan, with Jacques Michon, "Editors and Editing," Encyclopedia of Literature in Canada, ed. W.H. New (Toronto: U of Toronto P, 2002) 329. 


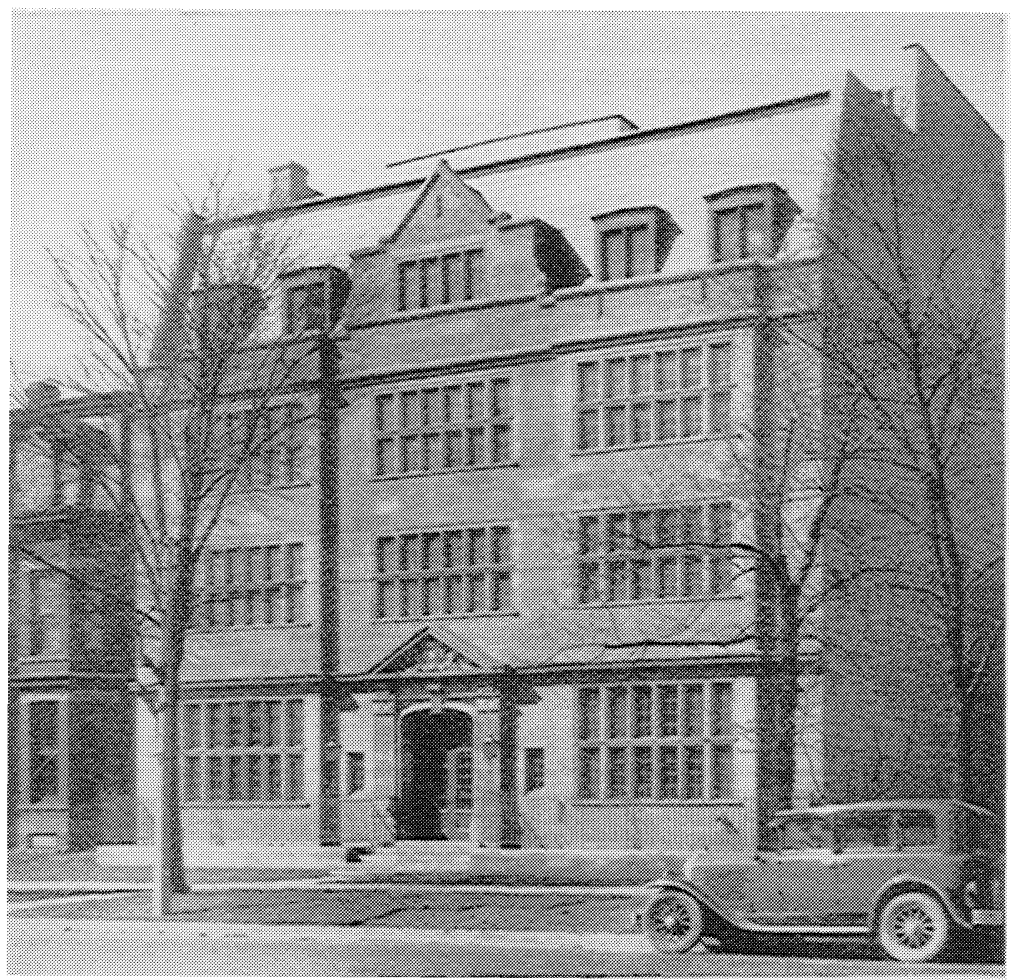

OX 0 O

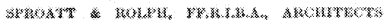

Figure 1. Photograph of Amen House in 1929, reproduced from: Sinaiticus, "Traditionalism in the Twentieth Century," Construction: A Journal for the Architectural Engineering and Contracting Interests of Canada 22.6 (June 1929): 174-78. 
will go on to show, that Oxford would resume publishing anthologies of Canadian writing.

Following Gundy's death in 1936, W.H. (William Henry) Clarke was appointed Manager of Oxford Canada. Bill Clarke was born in Lindsay, Ontario, and educated at the University of Toronto. Like his predecessor, he was a veteran of the publishing business. Prior to joining Oxford, Clarke worked at the Maclean Publishing Company and the Macmillan Company of Canada. In 1930, he left Macmillan and with his brother-in-law, John Coverdale Watson Irwin, founded the publishing house Clarke, Irwin and Company Limited. Throughout his tenure at Oxford, Clarke managed the Press "with much honour both to O.U.P. and to himself, while carrying on at the same time his onerous duties as head of Clarke, Irwin."II That no one understood "the rather involved relationship" I2 between Oxford University Press and Clarke, Irwin better than Clarke himself is revealed in a frank letter to author Paul Hiebert, dated I4 April 1948:

[S] ince 1936 these two organizations have been under joint management, and I have been enormously helped in the operation of both of them by maintaining a good deal of flexibility in the duties and responsibilities of what has really amounted to a joint staff. Actually there is quite a distinct separation between the two, as they are financially entirely independent of each other, and they have gradually resumed their original independence in almost every other respect, except management. ${ }^{\mathrm{I3}}$

The following year, after more than a decade at the helm of Oxford, Clarke resigned in order to manage his own company.

It was Clarke's good fortune to head Oxford during a period of revitalizing change in the publishing industry which saw a dramatic increase in the market for Canadian titles. During the Second World War, when government advocacy of cultural industries fostered an

II "Alumni Choose New President," Alumni Bulletin [U of Toronto] (Dec. 195I): 6.

I2 W.H. Clarke to Paul Hiebert, I4 Apr. 1948, Oxford University Press Canada archive, Toronto.

13 Roy MacSkimming describes a similar arrangement between McClelland \& Stewart and J.M. Dent \& Sons, with John McClelland serving as chairman of Dent's board in Canada. As he explains, "cooperative alliances allowed Canadianowned firms to profit from the presence of foreign-owned publishers without losing their identity or independence." The Perilous Trade: Publishing Canada's Writers (Toronto: McClelland \& Stewart, 2003) 7I. 
interest in Canadian writing, Canadian books sold in unprecedented numbers to a widening audience. ${ }^{14}$ Lovat Dickson, one-time Director of the Macmillan Company in Britain, explains:

This was a propitious time to take charge of a Canadian publishing company. The long servitude of the industry to its British and American overlords, which had made many publishers no more than importing agencies, was about to be transformed. Given full power and resources, limited only by British Exchange Control restrictions, ${ }^{15}$

publishers were provided with opportunities to transform the Canadian publishing industry.

In spite of Dickson's claim, resources remained limited. Out of financial necessity, publishers continued as agents for British and American houses, but Canadian publishers did prosper in the post-war years. The years 1945 and 1946 saw an impressive rise in production of Canadian titles, ${ }^{16}$ and a maturing nationalism fed a growing awareness of and desire for Canadian art and culture. The Canadian Broadcasting Corporation and Radio-Canada, for example, which developed during the I940s and I950s, featured writing by Canadians. Program organizer Robert Weaver joined the $\mathrm{CBC}$ in 1948 and began immediately to solicit work by Canadians, airing selections regularly on programs such as Canadian Short Stories (1946-54), CBC Wednesday Night (1947-63), Critically Speaking (1948-67), Anthology (1954-85), and Stories with John Drainie (1959-65). ${ }^{17}$

Under Clarke's knowing hand, Oxford's publishing program expanded between 1936 and 1949, and its reputation as a publisher of Canadian books was enhanced. In 1943, for example, Clarke oversaw publication - from plates shipped overseas from England - of the King James Bible, "the first time the Bible had been produced in the Dominion." ${ }^{\text {" }}$ The Bible was printed by Ryerson Press and published

I4 George L. Parker, "Publishing History," Encyclopedia of Literature in Canada, ed. W. H. New (Toronto: U of Toronto P, 2002) 910.

I5 Lovat Dickson, "Gray, John Morgan," The Oxford Companion to Canadian Literature, ed. Eugene Benson and William Toye, $2^{\text {nd }}$ ed. (Don Mills, Ont.: Oxford UP, 1997) 492.

I6 Delores Broten and Peter Birdsall, Paper Phoenix: A History of Book Publishing in English Canada (Victoria: CANLIT, 1980) 23.

17 W.H. New, A History of Canadian Literature (Montreal: McGill-Queen's UP, I989) I8I.

I8 William Henry Clarke, "An Art, a Craft, and a Business," William Henry Clarke 1902-I955: A Memorial Volume (Toronto: Clarke, Irwin, n.d.) 25. 
by Oxford. Throughout the I940s, a fertile decade for Oxford Canada imprints, Clarke published Poems (1946) by Robert Finch, literary works by Emily Carr - Klee Wyck (194I); The Book of Small (1942); The House of All Sorts (1944); Emily Carr: Her Paintings and Sketches (1945); and Growing Pains: The Autobiography of Emily Carr (1946) - and by Paul Hiebert, whose satiric work Sarah Binks (1947) was acclaimed in 2003 as one of five CBC Canada Reads titles. Clarke also issued works of history, including F.R. Scott's Canada Today: A Study of Her National Interests and National Policy (1938); Watson Kirkconnell's Canada, Europe, and Hitler (1939); D.C. Harvey's The Heart of Howe: Selections from the Letters and Speeches of Joseph Howe (1939); B.K. Sandwell's The Canadian Peoples (194I); Eugene Forsey's The Royal Power of Dissolution of Parliament in the British Commonwealth (1943); and Wilfrid Eggleston's The Road to Nationhood: A Chronicle of Dominion-Provincial Relations (1946).

Clarke took advantage of the new interest in Canadian books and he was successful in boosting Oxford's production of Canadian titles. His list reflected an emerging taste for books about national identity, Canadian culture, and Canada's role in world events, in particular the Second World War. Clarke's commitment to managing Oxford's branch operation in Toronto while building an impressive list of Oxford Canada imprints attests to his ability as a publisher and his vision as a bookman. His efforts on behalf of Oxford and its authors did not go unrecognized. During the 1940s, Oxford titles garnered prestigious awards, including Governor General's Awards for Carr's Klee Wyck (non-fiction 194I); Alan Sullivan's Three Came to Ville Marie (fiction 194I); Edgar McInnis's The War: Fourth Year (non-fiction 1944); Finch's Poems (poetry 1946); William Sclater's Haida (non-fiction 1947); and a Stephen Leacock Memorial Medal for Hiebert's Sarah Binks (humour 1947).

Clarke's success was due, in part, to careful management. He "brooked no argument about wages, allowed no smoking or alcohol consumption, and gave as an annual bonus a Christmas dinner at the King Edward Hotel, with a silver spoon as a gift, an author as guest speaker, and skits by the staff." ${ }^{\text {"9 }}$ Clarke's foresight and judgement leavened the often demanding work of publishing, however. The gentle irony of "The Oxford Anthem," which survives in the archives

I9 William Toye, "Retirement Address, Royal Canadian Yacht Club, 17 June 1991," ts., 2 . 
of the Canadian branch, evokes the congenial culture of the Press under Clarke:

O Oxford Press, O Oxford Press, we love Thee most sincerely:

We're overworked, and underpaid,

Yet all Thy orders are obeyed,

O Oxford University, we love Thy Press so dearly!

When we forget, or when we err, results are most distressing:

Thy methods are not ordinary,

But healthy and disciplinary,

O Oxford Press, O Oxford Press, Thou art indeed a blessing!

In days of boobs, or of disgrace, Thou preachest resignation:

Thou stretchest our ability,

And teachest us humility,

Never hast Thou been boring yet, Thou art our consolation!

We never read an Oxford Book, Bible, or Dictionary:

We do not publish, but promote,

And sell what somebody else wrote,

We educate, we sanctify, and drink at the Canary!

We've been chopped up, we've been locked up, into many

compartments:

We're broken in, and standardized,

We're beaten up, and organized,

Each one of us can thus ignore all the other Departments!

Without Thine overwhelming rule, we'd be but fractions mere:

But thanks to Thee, O Oxford Press,

We operate in such a mess,

O Domine, O Domine, illuminatio mea!

Little mess, in fact. Under Bill Clarke's direction, Oxford University Press prospered. By 1949, when Clarke resigned as Manager of the Press, Oxford was a successful branch operation with a record of publishing important Canadian titles. Clarke's departure from Oxford, though understandable and laudable, was a loss to the company and his lead would prove difficult to follow.

In 1949, Clarke was succeeded by C.C. (Charles Cannan) Johnson whose family had long been associated with Oxford University Press. Johnson's grandfather had been a Fellow of Trinity College, Oxford, and Secretary to the Delegates of Oxford University Press, and his father had been Printer to Oxford University. Prior to joining Oxford, Johnson had served in the British army. A "bright, energetic young 
man," ${ }^{20}$ he was appointed Manager of the Toronto branch only to confront various challenges.

During the late 1940s and early 1950s, when publishers faced a significant increase in the cost of materials, production, and labour, many issued fewer Canadian books as one means of minimizing financial loss to their businesses. This was not surprising, since publishers often had lost money on the weak sales of Canadian titles. Canadian books could not compete with popular, inexpensive paperbacks or the luxury items that had become available to consumers after the war. ${ }^{21}$ In 1955, John Morgan Gray, President of the Macmillan Company of Canada, understood that Canadian literature still lacked "a rational commercial basis, and must for years to come"; he wrote that "[i]maginative publishing and a tightly planned business operation are mutually exclusive; [and] the result is that Trade publishing ... is always in something of a turmoil." 22

Like most Canadian publishers, Oxford relied on profits from textbooks to support the publication of less lucrative undertakings such as works of poetry and history. One such textbook, The Canadian Oxford School Atlas, was issued in 1957 under Johnson and became a "good example of what an international publishing house can do in a very Canadian way." 23 "Tailored to the requirements of the Ontario Ministry of Education," ${ }^{24}$ it soon was adopted for classroom use by schools across the country and would undergo three revisions by 1979 . Annually, from 1958 onward, The Canadian Oxford School Atlas "sold in six figures, 'without any problems at all."'2s Without the profits from such "famous" 26 educational titles, the cost of publishing poetry and books on art and architecture, for example, would have been prohibitive. Through its successful educational list, Oxford ensured its survival as a publishing house and realized its commitment to issuing important Canadian books. As the Press announced in 1953, "[we are] watching for the good Canadian books. Some we have had

\footnotetext{
20 W[illiam] A[rthur] D[eacon], "The Fly Leaf," Globe and Mail I Oct. 1949: I2.

2I Broten 23.

22 John Morgan Gray, "Book Publishing," Writing in Canada: Proceedings of the Canadian Writers' Conference, Queen's University, 28-3I July, 1955, ed. George Whalley (Toronto: Macmillan, 1956) 63, 56.

23 "Profile," Quill \& Quire 6 Mar. 1970: 5.

24 MacSkimming 74 .

25 "Profile" 5.

26 "Oxford University Press Canada: $75^{\text {th }}$. Anniversary 1904-1979," [Toronto: Oxford UP, 1979] n.p.
} 
the honour to publish already: we confidently hope ... to publish an increasing number." 27

During Johnson's tenure as Manager, Oxford issued an eclectic mix of Canadian titles: G.P. de T. Glazebrook's A History of Canadian External Relations (1950); Indian tales by Cyrus MacMillan (Glooskap's Country 1955); Ivon Owen and William Toye's A Picture History of Canada (1956); volumes of poetry by Jay Macpherson (The Boatman 1957) ${ }^{28}$ and George Johnston (The Cruising Auk 1959); Alan Gowans's Looking at Architecture in Canada (1958); and William Toye's The St. Lawrence (1959). That Oxford's list was diverse throughout the I950s, despite the financial exigencies of the decade, was a sign of the Press's developing maturity.

Although Johnson "had a troubled career, and troubled relationships with people" ${ }^{29}$ - he struggled with alcoholism and his behaviour was erratic - William Toye, who joined the Press in 1948, experienced his generosity. In spring 1953, Johnson gave Toye "two months' leave with pay to visit the business in London and Oxford and to have a grand tour of Europe ... a wonderful act of kindness to a young employee"(II). Ivon MacLean Owen, who joined Oxford in 1947, also admired Johnson for his foresight. Johnson allowed Owen "to spend over half my time for two or three years planning and editing" 30 The Canadian Oxford School Atlas which became a landmark book for the Press. In I962, poor health forced Johnson to return to England where he died the next year. Roy MacSkimming has described Johnson's period of recovery in Oxford where "he resumed working at head office, expecting to be restored eventually to his position in Toronto. But in 1963 , while still in England, he either fell or jumped from a moving train, still carrying his briefcase, and was killed. The coroner's jury returned an open verdict on the possibility of suicide." ${ }^{\mathrm{I}}$ During Johnson's absence, Owen served as Acting Manager. He was appointed Manager in 1963, the same year the Press moved to its current location at 70 Wynford Drive in North York, a modern complex of brick and concrete designed by Toronto architects Robert Fairfield and Macy DuBois.

27 "O.U.P.: A History of the Canadian Branch of the Oxford University Press," CLA Bulletin 9 (Jan. 1953): 100.

28 The Boatman received the Governor General's Award for poetry in 1957.

29 Toye, "Retirement" II.

30 "Profile" 5.

3I MacSkimming 74 . 
Ivon Owen was born and educated in Toronto, at Upper Canada College and the University of Toronto. A man of intelligence and "catholic" 32 interests, he joined Oxford following graduation, first as Manager of the College Division and later as Editor and Chief Editor. Under Owen, "the Toronto office was free to publish whatever it saw $\mathrm{fit}^{\prime \prime 3}$ and Oxford grew increasingly Canadian in character.

Owen's years at Oxford coincided with those of William Toye who was hired by Owen to work in the Order Department at a salary of \$30.00 per week. Like Owen, Toye was a native of Toronto; he was educated at North Toronto Collegiate Institute and the University of Toronto. Toye was made Trade Editor in 1963 and Editorial Director in 1969, a position he held until his retirement in 1991. A gifted and rigorous editor, Toye regarded Owen as his "intellectual mentor and close friend." ${ }^{34}$ The two men worked closely during Owen's tenure as Manager. ${ }^{35}$ Owen recognized, however, that Toye made "the real decisions" $;{ }^{36}$ that Toye's contribution to the Press "is ... far greater than mine ... My role is to provide a climate in which ... [he] and others can do the things they do so well." 37

Toye helped shape Oxford's publishing program, in particular its list of modern Canadian titles. Between 1948 and I991 - he worked under five different Managers (Clarke, Johnson, Owen, Lorne Wilkinson, and Michael Morrow) - Toye was responsible for building Oxford's reputation as a publisher of important, welldesigned Canadian books. His "patient toil raised the standards of Canadian publishing" and he was "responsible for influencing the profession" ${ }^{\prime 38}$ in a profound way. In large part, the legacy of Oxford Canada remains that of Bill Toye. Toye was a natural bookman of prodigious talent. He tells a story

that sounds apocryphal but that I remember quite clearly. When I was under ten - because my father died when I was that age - I was being driven down University Avenue towards his office on

\footnotetext{
32 "Profile" 5.

33 George Galt, "Books: Boon Companion," Saturday Night 99 (Mar. 1984): 65.

34 Toye, "Retirement" II.

35 Owen and Toye were among the founding editors of the literary quarterly Tamarack Review (1956-1982). The other editors were Kildare Dobbs, Millar MacLure, Robert Weaver, and Anne Wilkinson.

36 Ivon Owen to Miriam Waddington, 26 May 1965, Oxford University Press Canada archive, Toronto.

37 "Profile" 5.

38 Cowan 328.
} 
a Saturday morning and we passed the Oxford University Press, just above Dundas on the west side of University. It was a very distinctive building, the replica of a Jacobean gentleman's London house, named Amen House after the OUP building in London. I of course didn't know any of these things, but I said: "I'd like to work there some day." 39

During his undergraduate studies, Toye's sense of vocation deepened. At a time when the wish "to enter the feeble Canadian publishing industry must have seemed eccentric," Toye knew that he "wanted to be a publisher's editor" (I). Prior to graduation, he applied to Oxford University Press and was hired to work in the Order Department where "every order and customer's name was recorded on a card bearing the author and title of a book, with stock totals reduced by hand according to orders" $(\mathrm{I}-2)$. Toye was elated to have been hired by Oxford and his commitment to the Press, evinced so early in life, never waned. He went on to enjoy a career at Oxford that spanned forty-three years.

During his career in publishing, Toye worked in the Order Department, as salesperson, production manager, and book designer. Occupied as he was, Toye believed that his publishing program "was more or less unplanned." ${ }^{\circ}$ By the 1960s, however, he was known among publishers, authors, and scholars primarily for his editorial acumen and his championing of Canadian literature. Toye referred to "instinct, taste, intuition, and sensitivity to language and nuance as essential qualities upon which editors depend," ${ }^{41}$ but he also appreciated the business side of publishing. He always was "sales conscious about our Canadian books. They are so expensive to produce and the market is so uncertain (and in some cases apathetic ...) that the kind of Canadian publishing we do can be most discouraging." ${ }^{2}$ Although Oxford Canada was largely independent, Toye understood the need for the branch to support itself and "show a profit," 43 always especially difficult in the Canadian market.

John Morgan Gray admitted in 1971 that "the present publishing situation in which Canadian books ride on imported books, or

\footnotetext{
39 Toye, "Retirement" r.

40 Qtd. in MacSkimming 8r.

41 Cowan 328.

42 Toye to Al Purdy, 30 Jan. 1970, OUP Canada archive.

43 Galt 65.
} 
schoolbooks, is less than satisfactory, even inhibiting." 44 As Gray implied, the late 1960s and early 1970s were challenging ones for Canadian publishing houses, despite the high point of Canada's centennial year. Following the Second World War, the domestic market for Canadian books did not increase significantly. Still, publishers sought to issue Canadian works in spite of the disadvantages that characterized their industry: the vast geography coupled with a small domestic market for books; the rising production costs; ${ }^{45}$ and the consequent need to continue as agents for foreign publishers.

In an effort to build a reputable list of Canadian titles while minimizing financial risk, Owen resumed publishing anthologies of Canadian writing, a practice initiated four decades earlier by Gundy. Since 1960, in fact, when Johnson issued poet A.J.M. Smith's The Oxford Book of Canadian Verse, anthologies have dominated Oxford's list and Oxford anthologies have been adopted for use in secondary schools and universities across the country. As a result, during the latter part of the twentieth century, Oxford Canada was instrumental in fostering the development of Canadian literature and in making it accessible to a wide range of readers through anthology publication. As MacSkimming has argued, "publishing anthologies was a way of showing the world that Canadian literature existed, by presenting a cross-section representative of the country's best writing. However arbitrary and exclusionary that taste-making process was, it stimulated wider recognition of a nascent national literature." ${ }^{6}$ Bill Toye, whose many connections with authors proved fruitful for Oxford, was the driving force behind the Press's series of successful anthologies.

In 1967, for example, A.J.M. Smith edited a second anthology for Oxford, Modern Canadian Verse. Between 1960 and 1991, the CBC's Robert Weaver, a founder and editor of Tamarack Review which showcased the work of Canadian writers, edited a series of five anthologies of Canadian short stories for Oxford. Gary Geddes and Phyllis Bruce's IS Canadian Poets, the first in a series of anthologies of Canadian poetry, was issued in 1970 and The Oxford

44 John Morgan Gray, "Trade Publishing in Canada," Publishing in Canada: Proceedings of the Institute on Publishing in Canada June 27-30, 1971, ed. G. Pomahac and M. Richeson (Edmonton: School of Library Science, U of Alberta, 1972) I2.

45 Bruce Whiteman, "The Archive of the Macmillan Company of Canada Ltd. Part I: 1905-1965," Library Research News [McMaster U Library] 8.I (Spring 1984): viii.

46 MacSkimming 76. 
Anthology of Canadian Literature, a comprehensive volume edited by Toye and Weaver, was published in 1973. Donna Bennett and Russell Brown's groundbreaking work, An Anthology of Canadian Literature in English, was published first in 1983 and has undergone two substantive revisions (1990; 2002). As Geddes recognized in 1984, "Oxford produces consistently better literary anthologies than McClelland and Stewart," 47 and Toye himself believed that Oxford "published more and better anthologies than any other publisher" 48 in Canada. Today, the Press continues to be known and respected for its anthologies of Canadian writing.

Under Toye, Oxford's publishing program soon expanded beyond anthologies to a wide range of Canadian titles, including children's books, scholarly books, works of reference, and volumes of poetry. Toye collaborated with illustrator Elizabeth Cleaver on eight picture books for children published by Oxford between 1968 and 1985 , for example. Sheila Egoffs The Republic of Childhood: A Critical Guide to Canadian Children's Literature in English was issued in 1967; Jean Sutherland Boggs's The National Gallery of Canada (197I) and Dennis Reid's A Concise History of Canadian Painting (1973) were two important books on art published by Oxford during the I970s. A self-taught and gifted book designer - from 1961 to I963 he was President of the Society of Typographic Designers of Canada - Toye often designed the books he edited. He enjoyed seeing a manuscript through the various stages of production, including editing, revising, designing, and publication.

Toye was best known, however, for his editorial work on several Oxford Companions. One of Toye's "most memorable experiences was editing" Norah Story's The Oxford Companion to Canadian History and Literature. The relationship between author and editor had a rocky beginning, however. In the early stages of writing the Companion, when Story objected to Toye's editorial changes and queries, she wrote complainingly to Ivon Owen. Much to Story's chagrin, however, Owen defended Toye: "[He] replied most supportively about my work, saying that I was helping her produce reasonably definitive entries, which he could see were being greatly improved." 49 After heated conflict and visits to a psychiatrist by Story, author and editor finally set aside their differences and worked

47 Galt 65.

48 Toye, "Retirement" 9.

49 Toye, "Retirement" 7. 
together as collaborators on a project that would win Story a Governor General's Award in 1967. Although Toye acknowledged that he acquired "a rather negative reputation for bringing about extreme revisions of books," he defended the editor's right to intervene and improve poorly written books: "Many of the books we publish are by writers who do not possess any marked writing ability, and the choice was to let them be incomprehensible, illogical, boring, and possibly incomplete in their information, or to try to make their texts clear and readable. I chose the latter course always"(Io). Toye's efforts on behalf of authors, which may have seemed severe to some, gave rise to his reputation as an incomparable editor and to Oxford's reputation as an excellent publishing house.

Under Toye's general editorship, a Supplement to The Oxford Companion to Canadian History and Literature was published in 1973. The success of the first Companion led to The Oxford Companion to Canadian Literature; dedicated to A.J.M. Smith and F.R. Scott, it was published in 1983 under Toye as general editor. A three-year project, it was undertaken with the "blessing" had been appointed Manager in December 1973 to succeed Owen. Owen's strengths lay in editing and in 1973, "while living under painfully difficult personal circumstances (the loss of both a son and his marriage," "II he was discharged as Manager. Toye served as Acting Manager for seven months until the appointment of Wilkinson.

Lorne Wilkinson was born and raised in northern Ontario and educated at the University of Toronto. Prior to joining Oxford, he worked for McGraw-Hill Ryerson for nineteen years, where he had risen to the position of Vice-President of the Marketing Division. As Toye explained, Wilkinson succeeded Owen "at a difficult time, [he] renewed the spirit of the firm with great adroitness and gave me every consideration." 52 Wilkinson was a strong manager who worked to maintain the financial health of the company. Soon after joining Oxford, for example, he streamlined operations and rented out office space on the second floor of 70 Wynford Drive as a costsaving measure.

The Oxford Companion to Canadian Literature was Toye's "magnum opus"; an unprecedented success, it sold close to 14,000 copies. ${ }^{53} \mathrm{~A}$

so William Toye, "Introduction," The Oxford Companion to Canadian Literature, ed. William Toye (Toronto: Oxford UP, 1983) xi.

sI MacSkimming 8r.

52 Toye, "Retirement" II.

53 MacSkimming 79, 80. 
second, expanded edition was published in 1997 under Toye and Eugene Benson as general editors, and a concise second edition edited by Toye was published in 200I. Toye's meticulous and erudite work on the Companion established his reputation as a leading authority on Canadian literature. In 1989, Oxford issued The Oxford Companion to Canadian Theatre edited by Eugene Benson and L.W. Conolly, the third in a series of groundbreaking and readable works of reference that offered "an unusual range of judgment." 54 Today, Oxford's Companions are regarded as invaluable sources of information and they serve as models for scholarly works of reference.

The satisfaction Toye derived from his work with books extended to his relationships with authors. Toye enjoyed close connections with a number of important Canadian writers whose work he edited. He once claimed to have "made friends of many of my authors"ss and, in fact, most writers appreciated the dedication of their editor and grew to trust Toye's skill and vision. In editing F.R. Scott's Selected Poems (1966), for example, Toye was anxious to produce an attractive book. In a letter to Scott dated 17 August 1965, Toye enclosed a sample page which he described as

handsome.... The type, which is Baskerville, suits your poems very well. (It happens to be one of the finest of all book faces.) Mr Moriss [from Moriss Printing in Vancouver], who visited me recently, is extremely anxious to do a beautiful job on your book. He is letting me use a second colour as decoration - on the title page and as section breaks - at no extra cost! He is a true craftsman and, as you know, his books are outstanding in appearance and workmanship.

Toye's attention to detail was impressive. Most of the manuscripts he edited "required great effort" - one critic described him as busily "rewriting other people's books" 56 - and authors were buoyed by Toye's enthusiasm and his commitment to excellence in book production. A.J.M. Smith had complete faith in Toye and placed "the book [Collected Poems 1962] - unreservedly in your hands. I am sure you will make a fine one. I will make such suggestions as occur to me but I am happy to leave final decisions with you. Let me have your ideas about title page, cover, and jacket." 57

54 Galt 63.

55 Toye, "Retirement" Io.

56 Toye, "Retirement" 9.

57 Smith to Toye, 13 Apr. 1962, OUP Canada archive. 
John Glassco also appreciated Toye's work on Memoirs of Montparnasse, published in 1970 by Oxford. Glassco admitted that Toye was instrumental in shaping his manuscript into a publishable book: "I am grateful to you - I can't say how much - for having cut down and re-structured my original rambling and complacent effort: this supplied a badly needed framework for what should, I see now, be as short and airy a piece of writing as possible." Glassco further urged Toye, "Make any other cuts you see fit, too." ${ }^{58}$ As the correspondence reveals, Scott, Smith, and Glassco formed lasting and personal associations with their editor. That each writer made Toye his literary executor testifies to abiding friendship and confirms Toye's ability and devotion to the authors whose work he edited.

In October 1965, Toye made "a definite commitment to publish" Miriam Waddington's The Glass Trumpet, although he asked that she agree to hold her

collection say until next January. Perhaps you will want to consider adding poems that you have written recently or may yet write, making substitutions in the collection as it now stands ... you will enjoy having time to mull over your typescript, knowing that a pleased and receptive publisher is looking forward to having it again next year. ${ }^{59}$

Toye went on to publish most of Waddington's books and he developed a warm relationship with the poet. He went to great lengths to design stunning books of poetry - a particular passion of his - and Waddington's collections of verse were no exception. In a letter dated I December 1984, Waddington revealed her indebtedness to Toye: "Oxford has published five of my books since 1966, and thanks to your editing, all of them have been good to look at, to hold, and to read.... I have always enjoyed the cordiality of my relations with Oxford, and I have appreciated and valued your meticulous and sensitive editing." ${ }^{60}$

That Toye was a reader of catholic taste is confirmed by the good will he engendered in writers, and by Oxford's impressive roster of poets. Under his editorial direction, Oxford also published the poetry of Margaret Avison, John Glassco, Phyllis Gotlieb, Daryl Hine, D.G. Jones, Patrick Lane, Pat Lowther, P.K. Page, Raymond Souster, and Francis Sparshott. Soon after Toye's retirement, Oxford

58 John Glassco to Toye, I4 Oct. 1969, OUP Canada archive.

59 Toye to Waddington, 29 Oct. 1965, OUP Canada archive.

60 Waddington to Toye, 1 Dec. 1984, OUP Canada archive. 
published volumes of selected poems by Roo Borson (1994), Mary di Michele (1995), Paulette Jiles (1995), and Erin Moure (1994).

At Toye's initiative, Oxford published Margaret Atwood's The Journals of Susanna Moodie (1970), regarded today as a landmark work. Oxford published most of Atwood's poetry, including three volumes of selected poems (1976; 1986; 1990), and Toye and Atwood developed a connection based on mutual respect and admiration. Atwood once wrote to Toye, "As usual after your inspirational phone calls, inspiration struck." "Toye's ability to inspire writers is evident in a letter to Atwood dated 24 January 1978:

I have just finished reading TWO-HEADED POEMS and hasten to write you ... to say that I am thrilled by it. Not just because it seems to excel your other poetry books in richness, but also because it is wonderful to observe a poet like you - always assured and successful - expand a remarkable gift, and use it with even more assurance and strength in new and memorable ways. There is no poem in the book that I don't like, admire, and want to go back to over and over. ${ }^{62}$

Toye's relationships with writers were characterized by the spirit of generosity that inspired his own letter to Atwood. Although he was a taxing editor, he repaid authors' efforts to improve their work with praise and the pleasure he derived from reading their manuscripts.

In spite of his determination to publish Canadian writing, Toye always was aware of the small market for Canadian books and the need for Oxford Canada to show an overall profit. Hence, he cautiously endorsed publication of $A$ Choice of Critics (1966), a selection of essays from the journal Canadian Literature which between 1959 and 1977 was edited by George Woodcock:

[I] $\mathrm{n}$ the realm of literary criticism, Canadian Literature, for what it has done and might yet do, probably deserves the recognition of a book to preserve its best offerings ... a book we wouldn't mind publishing. It would perhaps be an uninspiring service to Canadian letters, but it would be a service, one that it would become us to perform. ${ }^{63}$

Toye's success can be attributed to his sharp editorial eye and his shrewd choice of Canadian titles. From his vantage point as an editor

61 Margaret Atwood to Toye, 23 Dec. 1969, OUP Canada archive.

62 Toye to Atwood, 24 Jan. 1978, OUP Canada archive.

63 Toye to Owen, 23 Jan. 1964, OUP Canada archive. 
who knew and appreciated Canadian writing, he could determine the viability of most projects and avoid failure. He would regret his decision, however, to reject Northrop Frye's The Bush Garden: Essays on the Canadian Imagination (Toronto: House of Anansi Press, 197I) on the grounds that it would not be a marketable book. ${ }^{64}$

As Ann Cowan asserts, Toye was the kind of editor who "makes choices which, however discreet and unobtrusive, have a profound effect on the course of an individual author's career and on the development of a nation's literature." ${ }^{65}$ Toye's editorial changes were "strictly faithful to the style of the author and the content of the book ... when these books are finished, I don't know what I've done and what the author has done. It all reads seamlessly to me, and my part in it vanishes: in my mind, and certainly in the author's." 66 Throughout the latter part of the twentieth century, Scott, Smith, Glassco, Waddington, Atwood, Woodcock - and other writers who enjoyed successful careers - were helped immeasurably by Toye's efforts to publish and promote Canadian literature. As Managing Director Michael Morrow confirmed - Wilkinson retired in 1986 and was succeeded by Morrow ${ }^{67}$ - "There is more than one Oxford Canada author who owes his reputation and prizes as much to Bill's editing as to his own prose." 68 Toye was a visionary whose love of language, literature, and typography found expression in the books he edited and designed for Oxford University Press. In fact, during the course of his career, Toye received his own share of awards, including the Canadian Association of Children's Librarians Book-of-theYear medal (1959; 1970); the Canadian Author's Association Vicky

64 William Toye, personal interview, I7 May 2003.

65 Cowan 326.

66 Qtd. in MacSkimming 86.

67 Michael Morrow was born in Canada and educated in Britain. Prior to joining Oxford Canada, he worked for Oxford University Press in England for thirteen years, where he had risen to the position of Director of the International Division. Toye acknowledged Morrow as "a mainstay in my work, evincing support at every turn" ("Retirement" II). In 1993, Morrow returned to Oxford University Press in England and was succeeded by Susan Froud as Managing Director. Prior to her appointment, Froud had been Education Editor at Oxford Canada. In 1999, Froud was appointed Director of the International Division of Oxford University Press and was succeeded by Joanna Gertler, current President of Oxford University Press Canada. Prior to her appointment, Gertler had been Production Manager at Oxford Canada.

68 [Michael Morrow], "William Toye," The Record [Oxford UP] 36 (Dec. 1991): 25 . 
Metcalf Award (1972); the Canadian Silver Jubilee Commemorative Medal (1977); the IODE Book Award (1978); and the Eve Orpen Award for Publishing Excellence (198I). Toye was made a Member of the Order of Canada in 1994; he received an Honorary MA from Oxford University in 1995 and an Honorary Doctorate from Victoria University in 2004.

As he acknowledged at the end of his career, Toye felt deeply indebted to the Press he served so well for forty-three years:

[W] hatever I did do could not have been done without the support and encouragement of others. The Oxford Press - which in a way I singled out as an object of dedication at an early age - not only provided me with a working life, but it has also enriched my life as a whole. ${ }^{69}$

Toye attributed his major achievement as an editor and publisher of Canadian books to the enabling managers and staff of Oxford. As the record confirms, Oxford University Press and Bill Toye - "with his high standards, his respect for learning, and the instincts as an educator that he brought to all his publishing" - were "a perfect fit." 70

Richard Teleky, who was hired by Oxford in 1976 and rose to the position of Managing Editor, was an especially congenial and stimulating colleague. Born in Cleveland, Ohio, Teleky immigrated to Canada in 1968 in protest against the Vietnam War. After completing his doctoral studies in English at the University of Toronto, he taught for three years at Toronto's York University before embarking on a career in publishing. Toye felt privileged to work alongside Teleky. An aspiring writer, Teleky was a "brilliant originator of ideas that came to life in books of his own as well as in some of mine." ${ }^{\text {II }}$

Toye was both mentor and friend to Teleky; they shared a passion for literature and a commitment to the development of Canadian writing. Teleky brought his own exacting standards to the editorial table. He continued Oxford's tradition of publishing the work of Canadian poets, including Avison, Hine, Lane, and Page, and he

69 Toye, "Retirement" II.

70 [Morrow] 25.

7I Toye, "Retirement" I2. Teleky is the author of Goodnight, Sweetheart and Other Stories (1993); Hungarian Rhapsodies: Essays on Ethnicity, Identity and Culture (1997); The Paris Years of Rosie Kamin (1998); and Pack Up the Moon (2001). Other writers who at one time worked at Oxford Canada include Margaret Christakos; Victor Coleman; Brian Henderson; Don LePan; Rhea Tregebov; and Dick Wright. 
conceived and edited the series "Studies in Canadian Literature," published by Oxford between 1987 and 1991. Teleky produced six impressive and enduring collections of essays by prominent writers Linda Hutcheon (The Canadian Postmodern: A Study of Contemporary English-Canadian Fiction 1988, and Splitting Images: Contemporary Canadian Ironies 1991); Janice Kulyk Keefer (Reading Mavis Gallant 1989); Robert Kroetsch (The Lovely Treachery of Words: Essays Selected and New 1989); Miriam Waddington (Apartment Seven: Essays Selected and New 1989; and Adele Wiseman (Memoirs of a Book Molesting Childhood and Other Essays 1987). Like Toye, he was a dedicated professional who took a personal interest in the writers whose books he edited. Waddington and Wiseman, for example, shared lasting connections with Teleky. In 199I, however, when Toye retired and Oxford would not appoint a new Editorial Director, Teleky left the Press to pursue his own writing.

In 1975, the Press announced that " $[b]$ ranch publishing, while it has not been on a large scale, has been sufficient to establish for Oxford ... a definite and widely recognized character as a Canadian publisher. ${ }^{72}$ In fact, the announcement understated Oxford's achievement as a Canadian publishing house. By the mid-r970s, the Press had made significant inroads as a publisher of Canadian books in the educational and trade areas. Moreover, throughout the I980s and well into the I990s, Oxford's list of Canadian titles continued to grow, as did its facilities. In 1980 an extension was added to the existing warehouse, and in 1997 a new warehouse was erected on site at 70 Wynford Drive. Although Toye's retirement marked a shift in focus for Oxford, away from trade books to a new emphasis on educational publishing, the Press has continued to make a "modest contribution to Canadian culture." 73 Moreover, as Oxford soon recognized, educational titles "also make their contribution - both financially and culturally - although more quietly"74 than trade books. The successful launching in 1998 of The Canadian Oxford Dictionary, a project initiated by Managing Director Michael Morrow and edited by Katherine Barber, testifies to Oxford's ongoing commitment to publish works designed to enrich the lives of Canadians. The Canadian Oxford Dictionary soon became a bestseller. Over I00,000 copies were

72 "Canadian Branch 'Biography," ts., n.p. OUP Canada archive.

73 "Canada," The Record [Oxford UP] 33 (Dec. I988): II.

74 "Canada," II. 
sold in its first year and the Canadian Booksellers Association named Katherine Barber Editor of the Year.

As a foreign-owned branch of a British publishing house "not eligible for government grants to support the publication of Canadiana," 75 Oxford's commitment to publish Canadian titles was and remains impressive. Oxford's current focus on educational publishing means that the Press will contribute more modestly to Canadian culture than it did during the latter half of the twentieth century. But Oxford has survived as a Canadian branch where others have failed. The Macmillan Company of Canada, for example, established in Toronto in 1905, was sold by its parent company in Britain to Maclean-Hunter in 1972. Today, Canadian publishing houses struggle to maintain their foothold in an increasingly global market and an industry that is vulnerable to foreign takeover and bankruptcy. As publishing historian George Parker admits, "the market is still heavily weighted towards imported books and ... international corporations and trade regulations are still determining factors." ${ }^{6}$ Oxford's recent decision to focus on educational titles may mean the loss of trade titles that established the Press's reputation for excellence in the field of Canadian publishing. For now, Oxford will no longer publish award-winning volumes of poetry or beautifully illustrated books for children, for example. The future holds the promise, however, of more useful, important, and attractive books distinguished by the Oxford imprint and designed to enliven the cultural landscape of Canada. ${ }^{77}$

75 'Canada' II.

76 Parker 914.

77 The in-house archive of Oxford University Press Canada was made available to me for the purposes of writing this essay. The archive covers the period 1904 - when Oxford first was established in Canada - to the present. The archive is extensive and includes documents such as executive and author correspondence; readers' reports; contracts; production and publicity files; financial material; and catalogues. Several years ago, the Press discarded all manuscripts and typescripts as a space-saving measure. The archive of Oxford University Press is valuable as a living record of the cultural history of Canada and as a resource for scholars across disciplines. This essay draws on that resource, used here for the first time for scholarly purposes, to illustrate Oxford's important role in the development of Canadian writing. 


\section{SOMMAIRE}

En août 1904, lorsque la maison d'édition Oxford University Press établit une succursale au Canada, elle rejoignit un petit groupe, quoique important, de maisons d'édition opérant à Toronto. En 1929, la succursale de Toronto pouvait annoncer avec beaucoup de fierté qu'elle représentait une maison avec de grandes traditions et avait à son compte du travail important, non seulement au plan du développement de l'impression mais aussi de l'histoire de l'Angleterre. Après vingt-cinq années au Canada, Oxford University Press avait commencé à réaliser ses espoirs d'expansion.

Les origines britanniques de la maison, toujours mises de l'avant en tant que source de fierté par la succursale canadienne, sont encore célébrées aujourd'hui. Au cours des dernières cent années, et particulièrement durant la période subséquente à la Deuxième Guerre mondiale, lorsqu'elle a contribué au développement des lettres et au façonnement de la culture au Canada, Oxford University Press a conservé la tradition britannique de publier des livres utiles, importants et beaux. Cet article montre qu'Oxford Canada s'est développée largement comme une succursale indépendante de la maison mère en Angleterre. En outre, n'ayant pas succombé aux caprices de l'insécurité économique qui a toujours caractérisé l'industrie de l'édition au pays, Oxford continue de s'engager à produire des livres canadiens qui reflètent la dignité de l'entreprise. Cet article s'inspire des archives internes d'Oxford University Press Canada, utilisées ici pour la première fois à des fins d'érudition, pour illustrer le rôle important qu'a joué Oxford dans le développement de l'écriture au Canada. 
